\title{
Alternative techniques of supplementary irrigation for the rain-fed paddy schemes in Brunei Darussalam: a case study of the Kg. Junjungan paddy scheme
}

\author{
K. B. M. Shafiuddin \\ Senior Lecturer, Civil Engineering, Institute of Technology Brunei, \\ Brunei Darussalam
}

\begin{abstract}
Brunei Darussalam is a hot and humid country in the equatorial region of Asia. Located on the island of Borneo, Brunei Darussalam enjoys moderate seasonal rainfall. It is green, rugged and hilly in the upland areas and fairly flat with valleys and swamplands near the coastal belt. Some areas are ideal for paddy cultivation. Emerging from the national urgency and "Grow More Food" crash program campaign, the $\mathrm{Kg}$. Junjungan scheme presents a proposal to convert from rain-fed paddy cultivation to fully irrigated paddy. The scheme area is nearly flat and suitable for paddy with a non-perennial stream flowing nearby. The scheme area also experiences flash flow after heavy rainfall events in the catchment. This water resource, valuable and scarce at times, flows down the stream untapped, while a nearby paddy scheme suffers for lack of water during a drought situation between two periods of rainfall events.

With a study at pre-feasibility level, this paper investigates the possibility of tapping the flash flow for the abstraction and diversion alternatives of surface water for irrigation by gravity or pump, or a combination of both.

Findings suggest that a pump station and a head works could be the best alternative of water abstraction from the stream. There would be an intake channel to the pump station and a conveyance canal from the pump station to the scheme area to ensure sufficient full supply level. If the drought situation worsens, another option is sub-irrigation by controlled drainage using the irrigation and drainage network for retention and control of ground water table in
\end{abstract}


the scheme area. This option will sustain crops during periods of extreme drought from wilting.

Keywords: supplementary irrigation, rain-fed paddy, drought, controlled drainage, wilting.

\section{Introduction}

There is plenty of rainfall in Brunei Darussalam throughout the year. After a rainfall event, sudden flash flows generate runoff which flows downhill. Nonperennial and perennial streams start flowing full and at times spill over their banks causing flooding and crop damage. At present, this precious water resource flows downstream unutilized, while nearby rain-fed paddy cultivation schemes suffer from lack of water. If these flash flows can be tapped/harvested, then the nearby rain-fed paddy schemes could be provided with supplementary irrigation during dry spells and droughts.

There are many rainfall-dependent paddy cultivation schemes in Brunei Darussalam; the Kg. Junjungan scheme is one such example. The risks and uncertainty associated with such schemes is very high. Rainfall intensity, duration and timing in relation to the crop calendar, etc. play a significant role towards the success or failure of a rain-fed paddy scheme, while there is always a risk of looking an entire harvest for lack of timely rainfall. Rain-fed paddy has hardly a harvest of one ton per hectare compared to 5-6 tons per ha if supplementary irrigation can be provided to convert it into an irrigated one.

In Kg Junjungan, the Agricultural Department of Brunei Darussalam has identified an area of nearly 100 ha suitable for an irrigated paddy scheme. At present, part-time farmers cultivate rain-fed paddy here, but they have indicated that the area gets flooded and damaged whenever there is a big rainfall in the catchment. The project area is affected in three ways, namely,

- Damage by flooding soon after heavy rainfall and over-bank spillage due to lack of protection from flooding

- Suffer from drainage congestion for lack of any drainage plan, and consequently

- Poor or no harvest when there are prolonged drought-like conditions.

\section{Project location}

The Kg. Junjungan Paddy scheme is located in the Brunei-Muara district of Brunei Darussalam. It is a rural area about $28 \mathrm{~km}$ south west of Bandar Seri Begawan, the capital city of Brunei Darussalam. The project area, roughly about 100 ha, is fairly flat, elongated and shares a border with the East Malaysian state of Sarawak (Ref: Figure 1). It suffers from flooding and drainage problems during heavy rainfall and from drought due to the absence of irrigation. A perennial river named 'Sg. Keduit', the only water source for the project, runs along the length of the project. A road named 'Jalan Junjungan' runs between the project area and the river along the length of the project area. 


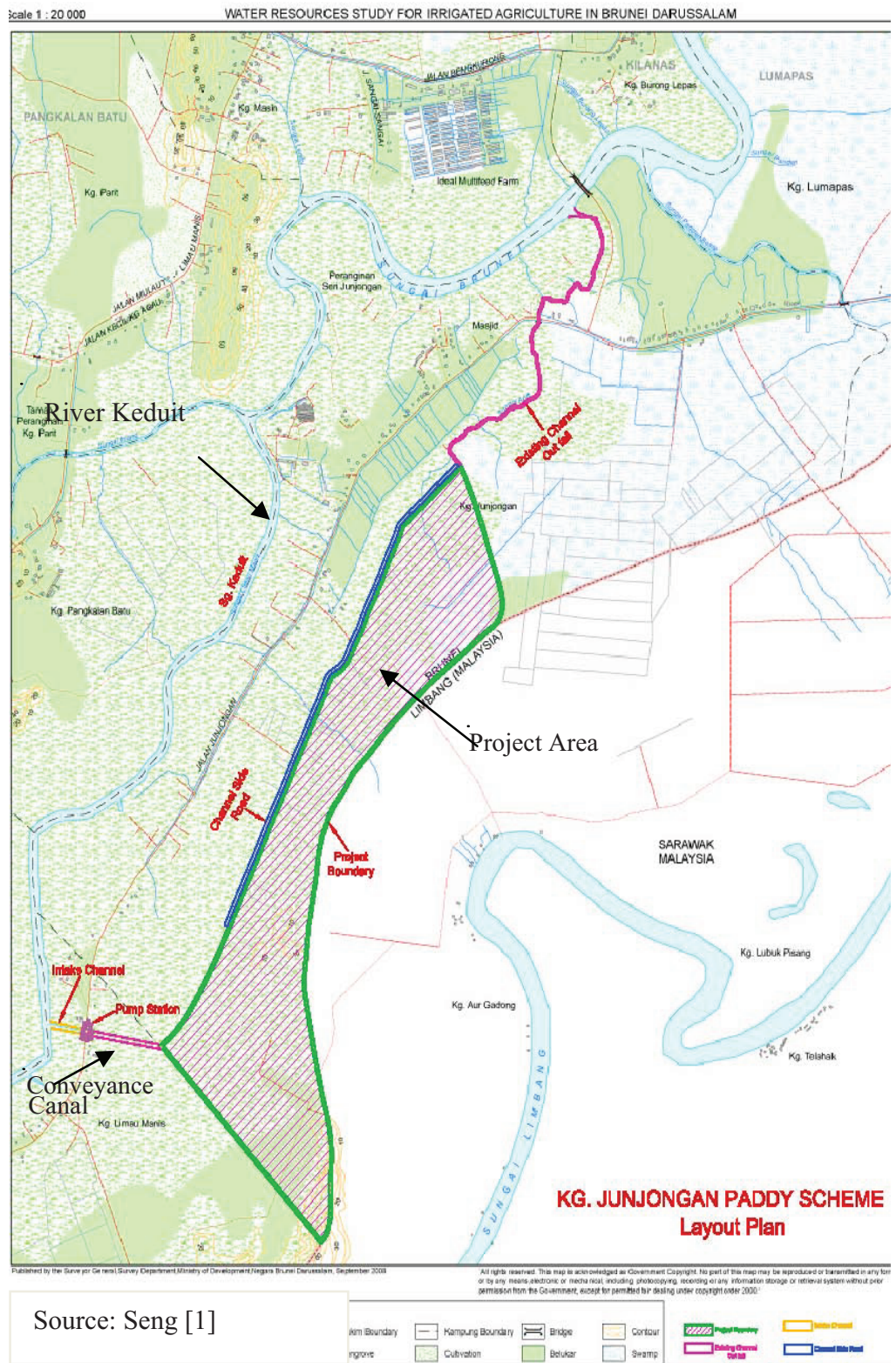

Figure 1: $\quad$ Project map (Seng et al. [1]). 


\section{Methods of irrigation}

There are many types of irrigation that can be considered for application in a project. Types of irrigation techniques differ in their method as to how the water is abstracted/diverted/obtained from the source and then distributed within the field. In general, the irrigation goal is to supply water to the entire field uniformly so that each plant has the exact amount of water it needs, neither too much nor too little.

The methods that can be considered for this project are surface irrigation for normal drought condition and sub-irrigation in extreme cases of drought

\subsection{Surface irrigation}

In surface irrigation systems, water moves over and across the land by simple gravity flow in order to wet the land and infiltrate into the soil. It is often called flood irrigation when the irrigation results in flooding or near flooding of the cultivated land (Figure 2). The Kg. Junjungan paddy scheme is no exception to that. Historically, this has been the most common method of irrigating agricultural land. This is often seen in terraced rice fields having moderate land reliefs; the method used is to flood and control the level of water in each distinct field. There are certain areas in this project where terrace fields would be a better option.

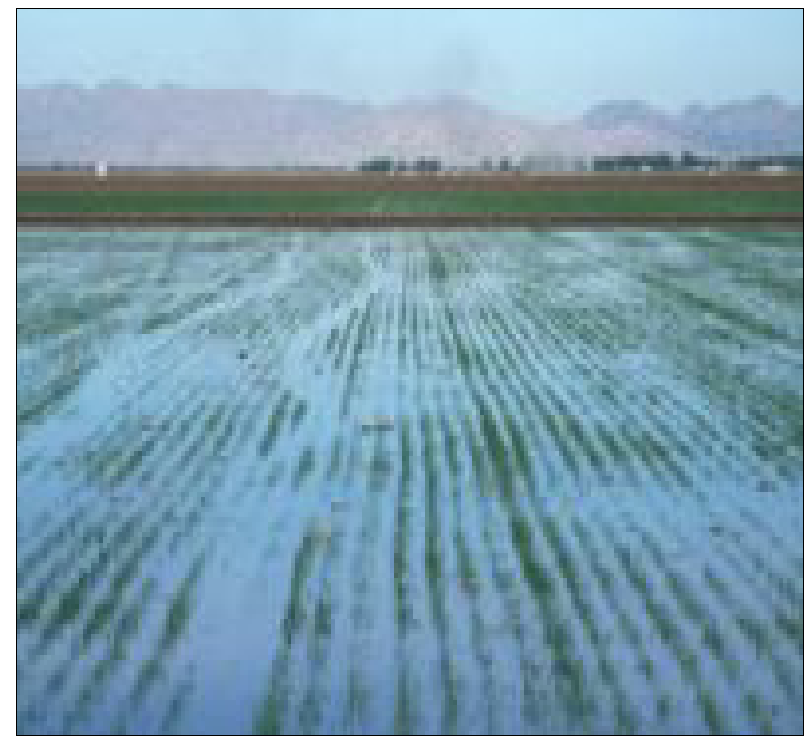

Figure 2: $\quad$ Surface irrigation by flooding (source: Marzuki et al. [2]). 


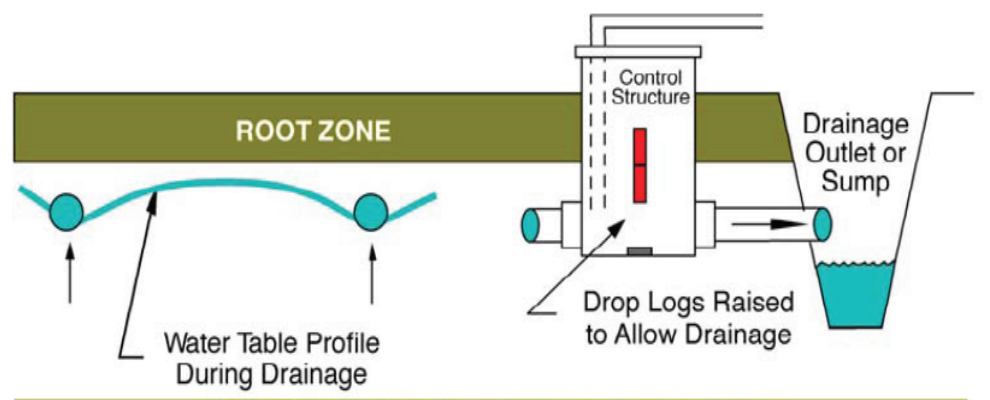

CONVENTIONAL DRAINAGE MODE

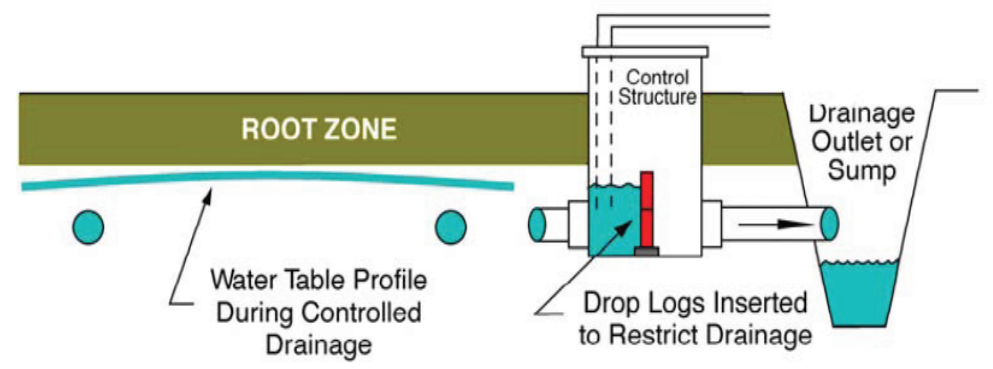

CONTROLLED DRAINAGE MODE

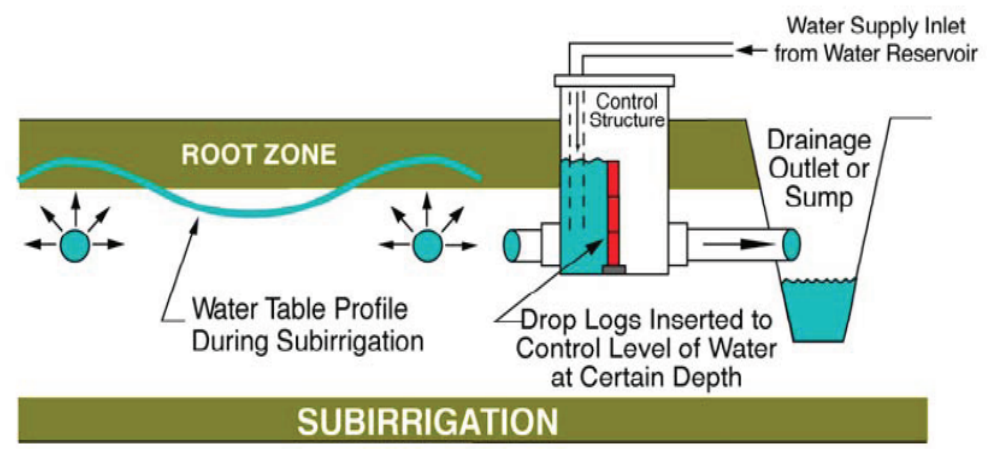

Figure 3: Controlled drainage and sub-irrigation (source - Dr. L. C. Brown $[6])$.

\subsection{Supplementary irrigation}

Supplementary irrigation, supplemental as the name implies, is the application of water to plant when natural precipitation is not adequate to secure crop. Depending on the size of the farm and the types of the irrigation system, 
application of supplementary irrigation is possible by using the water sources made available by storage/abstraction by pumping from streams, reservoir, pond and rivers.

Supplementary irrigation techniques are means and methods of irrigation by diversion of surface water from streams or abstraction of ground water and then irrigating by gravity through the infrastructures and networks of irrigation and drainage.

The Kg. Junjungan paddy scheme is an ideal case of rain-fed paddy scheme where supplementary irrigation is absolutely essential to irrigate during the drought periods.

Paddy is 80 to $95 \%$ water dependent and hence its performance with respect to yield and quantity can suffer from wilting to due water stress or drought (Rice [4]). If the water shortage occurs early in the crop's development, maturity may be delayed and yield could be reduced significantly. If the moisture shortage occurs later in the growth seasons, the quality of growth is often reduced even though total yield may not be affected. The timing of supplementary irrigation after the rainfall event and its relevance to the crop calendar has a significant relationship in the case of this project as well. The crop calendar for paddy in Brunei Darussalam is contained in the rainy season, roughly from September to January.

\subsection{Sub-irrigation}

Sub-irrigation by drainage control, sometimes called seepage irrigation, can be used for field crops in areas with high ground water tables. It is a method of artificially raising and maintaining the water table to allow the soil to be moistened from below the plants' root zone. A system of pumping stations, canals, weirs and gates allows it to increase or decrease the ground water level. Figures/sketches of sub-irrigation by controlled drainage are shown in Figures 3 illustrating the stages of conventional drainage, controlled drainage to achieve sub-irrigation (Brown [6]).

\section{Drainage}

Drainage is an integral part of any irrigation project. Drainage is a system to flow water out of an area. It is just as important to ensure that the fields do not receive too much water as it is to ensure that they do not receive too little water. If drainage is inadequate, a process called salination may occur, in which salt accumulates.

Another danger of insufficient drainage is water logging, which has also occurred in the $\mathrm{Kg}$ Junjungan rain-fed paddy scheme. Not knowing the drainage direction and unplanned drainage initiative by the local farmers have worsened the situation resulting in prolonged drainage congestion and water logging.

In the water logged situation, the water table remains raised due to the excess amount of rain irrigation at a rate faster than it can possibly lower itself by natural percolation processes. Additionally, when the water table is high, more 
evaporation occurs, which leaves behind more salt in the upper soil profile and further exacerbates the salination problem.

To prevent salination and water logging, adequate and efficient drainage network is essential to go hand in hand with any irrigation system.

Table 1: $\quad$ Drought analysis (source: Seng et al. [1]).

Rainfall Data Analysis for Drought Periods (1996-2007)

\begin{tabular}{|c|c|c|c|c|}
\hline $\begin{array}{l}\text { Drought } \\
\text { Duration } \\
\text { (Days) }\end{array}$ & $\begin{array}{c}\text { No. of } \\
\text { Occurrence }\end{array}$ & $\begin{array}{c}\text { Cumulative } \\
\text { No of } \\
\text { Occurrences }\end{array}$ & $\begin{array}{c}\text { Percentage } \\
(\%)\end{array}$ & $\begin{array}{c}\text { Cumulative } \\
(\%)\end{array}$ \\
\hline 1 & 205 & 374 & 55 & 55 \\
\hline 2 & 79 & 169 & 21 & 76 \\
\hline 3 & 47 & 90 & 13 & 89 \\
\hline 4 & 23 & 43 & 6 & 95 \\
\hline 5 & 12 & 20 & 3 & 98 \\
\hline 6 & 4 & 8 & 1 & 99 \\
\hline 7 & 2 & 4 & 0.5 & 99.5 \\
\hline 8 & 1 & 2 & 0.25 & 99.75 \\
\hline 9 & 1 & 1 & 0.25 & 100 \\
\hline
\end{tabular}

( $89 \%$ of the drought conditions are in the range of 3 days or less.) 


\section{Drought and rainfall study}

Globally a drought in general is considered to be a long period of very dry weather for weeks or even months with little or no rain. Definition of drought for paddy is very different as paddy cultivation is heavily dependent on water; even a drought-like period of 2 or 3 days could be very detrimental or damaging in terms of a good harvest.

Drought is the main hindrance to rain-fed paddy. Uncertainty of adequate rainfall for a good harvest is beyond the control of the farmers. A reasonably thorough study of rain harvest, rainfall intensity and number of occurrences will determine the size and frequencies of drought periods best suited for management by supplementary irrigation.

A fairly detailed study of rainfall and drought events was conducted for the project with real time rainfall data for the area from 1996 to 2007. The study revealed that $89 \%$ of the drought conditions are in the range of 3 days or less. It would be a fair estimation of drought condition to consider in the design of supplementary irrigation (Nordin et al. [3]).

Rain water harvest is a proven technology to supplement irrigated paddy in drought prone areas when water is not available in lean periods.

\section{Method of abstraction}

Considering the afflux elevation and quantum of water resources available, appropriate techniques of supplementary irrigation for the $\mathrm{Kg}$ Junjungan Scheme can be one or more of the following abstraction and diversion options:

\subsection{Dam and reservoir}

Construction of a dam creates a storage reservoir upstream with high storage and afflux level. This technique requires huge capital expenditure and is generally applicable for big multi-purpose projects having command areas in the order of few square kilometers and more. Normally the dam site is selected in such a way that it will not only provide huge storage reservoir but a significant energy head and afflux as well so that irrigation application is easily achievable entirely by gravity flow. Kg. Junjungan paddy is only a 100 ha scheme and the nonperennial Keduit River flowing nearby has flash flow after a heavy rainfall in the catchment. The concept of dam and reservoir is technically and economically out of question. More over there is no significant area in the catchment where a 'Dam and Reservoir' concept can be adopted.

\subsection{Diversion weir and headworks}

This technique is applicable for moderate size projects requiring low head afflux created by construction of a weir on the stream and headworks for irrigation diversion. There should be enough lean flow storage and the diversion weir will provide the required head for gravity flow. 
This technique is not feasible for the Kg Junjungan scheme as the lean flow level is well below the level needed for canal flow by gravity in the project. Construction of weir will not provide the required afflux and head needed. Moreover, flood flow is quite high and would require a very robust construction of diversion weir and head works of high capital expenditure.

\subsection{Pump station and headworks}

This technique is suitable where the abstraction head is moderate. A pump station with suitable operating head would need to be installed for abstraction of water from the stream at lean flow period. For this project size, one pump and a stand by would possibly suffice.

This system fits well with the Kg Junjungan scheme as the level difference between stream lean flow and full supply level needed for the scheme are such that it would require pumping any way. The low water level is at least $3 \mathrm{~m}$ below the normal ground level in the project area. The Keduit River is tidal and the salt content is well within the tolerable limit for paddy. High tide periods will be an advantage for abstraction due to backwater effect.

An intake channel and pump station can be built. Incidentally, at the initiative of local farmers, a channel has already been dug at an upstream point of the project, but this is unsuitable for drainage purposes. This channel can easily serve as an irrigation intake channel from the stream to the pump station (ref: Fig. 1). The farmers at their own initiative have also constructed a drainage channel at the downstream end which will act as drain and outfall channel.

If economically justifiable, a low head submersible weir would be ideal for the scheme, as it would create a better afflux and lower suction head for the pump. The selection of the crest level of the weir should allow for safe passage of the flood flow, while the residual storage behind the weir should give enough storage to pump water up to the conveyance canal to meet supplementary irrigation requirements during drought periods. The weir should preferably be a broad crested one robust enough for stability while allowing passage of flood water.

\section{Finding and recommendations}

- The Kg. Junjungan paddy scheme suffers badly almost every year due to drought and flood.

- $\quad$ Part time farmers are reluctant to invest properly due to unpredictable rainfall and drought, and the uncertainty of a good harvest. They are on the lookout for better income elsewhere.

- At present, only rain-fed paddy is cultivated at the project area, and the yield is only less than a ton /ha even during a good rainfall event.

- The project area presently lacks from any irrigation and drainage infrastructure.

- $\quad$ River Keduit is a non-perennial stream and at times carries flash flow soon after a heavy rainfall event in the catchment. 
- Water resource from rain harvest and storage in the River Keduit appears to be adequate, but needs further study.

- $\quad$ Farmers will be motivated to become full time farmers if the project area is protected from flooding and supplementary irrigation is provided during drought.

To reverse this scenario, this pre-feasibility study revealed the following:

- Low height flood dykes can be constructed economically to protect the project area from flooding.

- Design drought period may be considered to be 3 days after studying the rainfall for 12 years (1996-2007). 89\% of the drought periods are 3 days or less during the paddy planting season of September to December.

- The flow capacity of River Keduit and online storage of rain harvest is expected to be adequate for abstraction and supplementary irrigation during drought.

- Few control structures will be required at strategic locations in the project to collect and maintain the required storage level by controlled drainage to save the crop from wilting in severe drought situations.

- $\quad$ Rain-fed irrigation supplemented by gravity and pump irrigation during drought will convert the project into a fully irrigated paddy project raising the yield from less than 1 ton per/ha now to potentially about 5-6 tons/ha with other usual inputs.

- The presently part-time farmers will be potentially motivated to become full time farmers. Moreover, there will be significant employment generation for farming and other associated economic activities.

- The success of this supplementary irrigation concept to rain-fed paddy will be a milestone to irrigated agriculture in the country and will ultimately lead to a green revolution in the agro-industry.

\section{References}

[1] Seng, L.J., Amin, A. M. and Hozaimi, H., Irrigated Agriculture in BruneiMuar district of Brunei Darussalam-, Student Project, ITB Nov. 2008

[2] Marzuki, A, Yusrin, A.M, Hozaimi, H. Irrigation and Drainage Study for Kg. Bebuloh Paddy Scheme, Student Project, ITB., Nov. 2006

[3] Nordin, M. H., Sulaiman, H S., and Azrin, J. Feasibility Study of Control Drainage and Supplementary Irrigation in Kampong Bebuloh Paddy Scheme. Student Project, ITB Oct. 2004

[4] Rice, E. B., Paddy Irrigation and Water Management in South East Asia, 64 pg. 1997

[5] Warren, V. Jr., Gary, L. L., 1996, Introduction to Hydrology, New Harper Collins College Publisher.

[6] Brown, L.C., Controlled Drainage -Overview and potential uses for liquid manure application on subsurface drained cropland, The Ohio State University (PP presentation slides) 